\title{
7. The end of hypocrisy Online activism and ethno-political conflicts
}

\begin{abstract}
In the past twenty years, democratic participation through activism and civil disobedience has been increasingly expanded with the evolution of information and communication technology. It is assumed that the role of traditional media is not as influential as it once was due to the growing presence of self-made war journalists, hacktivists and whistleblowers, facilitated through the potential of the internet. The use of the latter as a tool from which information is disseminated rapidly, is fast influencing societal understanding and exposure to issues as they develop. Social media demonstrates precisely this phenomenon, in which people are able to accrue information and act upon it through mass communication and mobilisation. This article will therefore endeavor to analyse the evolution of media in conjunction with activism, from traditional media ethno-political conflict reporting, to today's whistleblowers and hacktivists that use the internet as their main platform. By factoring in these different aspects, this article is able to present a detailed account of the advantages and drawbacks of the latest developments in internet and technology, with special emphasis being placed on the role of online activism.
\end{abstract}

Keywords: Anonymous, activism, censorship, civil disobedience, cyber activism, democracy, hacktivists, mobilisation, peace journalism, propaganda, social media, technology, war correspondence, WikiLeaks, whistleblowers

\section{GEORGIOS TERZIS}

Vesalius College and IES, Vrije Universiteit Brussel

\section{Introduction}

A CTIVISM and civil disobedience has always been part of democratic participation, yet in the past twenty years the activists' landscape has significantly broadened with the evolution of information and communication technology. But while the internet is generally considered a tool for more cooperation, public participation, and democracy, others consider it as a cause of increased political violence and a peril for societies.

Regardless of one's stance, there is no doubt that the internet created new opportunities for peace activism and conflict management. Mesthene captured already in 1986 a more 'balanced' understanding of the relationship between the internet and society when he stated: 'New technology creates new opportunities for men and society, and it also generates new problems for them. It has both positive and negative effects, and usually has the two at the same time and in virtue 
of each other' (Mesthene, 1986, p. 76). In recent years especially, the internet has begun demonstrating the extent of its efficacy in challenging old traditional media structures, increasing the proximity of the public to the decision-making process by conveying a message, rallying support and implementing change; for both non-violent and violent initiatives. This article will therefore be an analysis of the impacts the internet has had in achieving just this.

Activism is no longer limited to picket protests that go through any weather condition, deal with any police force and spend the majority of their time collecting money to fund their actions. All one seems to need today is a computer, an internet connection and a good network of netizens. This is particularly troublesome in light of times of war and conflicts, in which society's support needs to be rallied by governments and its interest maintained through the predominant course of traditional media information from a one directional top-down flow. The internet is challenging precisely this structure, allowing people to mobilise themselves in order to voice discontent and implement change for instance through peace campaigns with the emergence of the e-movements.

Today initiatives are essentially born and publicised to a large targeted group in a matter of minutes (e.g. 'Kony 2012') through social media platforms such as Facebook, Twitter, YouTube and others. Such advancements are made possible by the nature of the internet itself, which enables the mass dissemination of information from a small or individual source which can reach wide audience, even in remotest places due to increasing internet connectivity and tech availability.

Technological advances and creativity are now, however, leading to a time in which the dissemination of sensitive information can help shape an activist campaign or can in itself be the reason for a campaign. Wikileaks for example, has shed new light on the 'freedom of expression and the freedom of information'. Moreover, the whistleblower website unleashed new campaigns against government practices, as Giri quoted in Zizek (2011, p. 409 ) puts it, WikiLeaks 'challenged power by challenging the normal channels of challenging power' i.e. the independent press, NGOs, etc.

Recently, this form of online initiative has opened the way for a new form of online activism led by 'hacktivitist', hacker groups using the advancements in technology and internet connectivity to target specific government authorities or companies in response to a specific event; for example Anonymous hacking inter alia Visa and Mastercard in response to the freezing of WikiLeaks' accounts. Although their efficiency has not been measured yet, it seems that hacktivists work mostly in conjunction with activist campaigns in order to provide support and ensure visibility.

\section{Ethno-political conflict in offline and online media}

Media plays a crucial role in the information wars that define the world today. 
This is because the media uses different channels and mediums, which are collectively used to communicate simultaneously to large groups of people; such as radio, television, magazines, newspaper and the internet (Howard, 2004, p.149). These media have played a significant role in the mediatisation of conflicts in their contribution to the dissemination of ideas, information and images about them (Cottle, 2006, p. 8).

Traditional media (consisting of the aforementioned media, excluding the internet), should operate according to normative theory with the intention of helping the public to make educated and well-informed decisions regarding current issues in a timely manner (Caparini, 2005, p. 43). The media as such is not only meant to serve as a tool for good governance by enabling communication exchange between the public and their leaders, but also to act as a mechanism of ensuring accountability by revealing wrongdoings, such as criminal misconduct and corruption. Essentially, they should be assisting in the democratic process by encouraging open debates while engaging the public and delivering reliable information; a crucial role because it is imperative that the public is well informed prior to making political decisions. This is especially important during times of conflict because of their consequences and especially the myriad of consequences that the decision to go to war brings with it, from the loss of lives, to economic costs in increased military expenditures, as well as political implications such as controls on civil liberties (Caparini, 2005, p. 31).

During such a time, the media is expected to provide the public with accurate information regarding the State's foreign policy, military strategies and the progress of the war as a whole, thus ensuring the continued inclusion of the public in the developments of State decisions. It therefore becomes imperative that the media, particularly news media, endeavour to operate in a balanced way because the information transmitted can serve to influence public opinion, for instance continuing to maintain public support for the decision to engage in war.

Accurate and balanced reporting is a critical component and ethos which should underpin journalistic practices, as the predominant aim is to uncover and deliver accurate information (Tumber, 2005, p.216). The accuracy and balance of information is also heavily affected by the source from which it is derived. For instance, official sources such as government authorities convey one perspective often through censorship, grey or black propaganda (White, 2005, p. 4), a practice which is also prevalent within the media industry (McGoldrick, 2005, p. 203).

This becomes problematic when such information is disseminated through traditional mass media sources, leaving the public to understand their situation in fragmented bits, limiting perspectives, influencing opinions, and in extreme cases, spreading negative and hateful sentiments to further support the State's predetermined agenda (White, 2005, p. 53). The latter in particular, features heavily within the realm of conflicts and violence covered in traditional media 
sources, often through the manipulation of information and images in the delivery of broadcasts (Howard, 2005, p. 149). Inevitably, such practices by traditional news media outlets work to create a chain of distrust between the various actors involved; for instance authority figures and media agents which culminates in sabotaging public confidence in the news (White, 2005, p. 54).

However, with the proliferation in internet connectivity and access to technology, traditional media and the legitimacy of their dispatches is being questioned and confronted. The internet is able to provide users with a multitude of alternative information sources, thereby sometimes reducing the effects of biases, disinformation, rumours, hate propaganda and other sentiments which can lead to increased tensions or induce conflicts. Offsetting the aforementioned information types can lead to the re-education of the parties involved in the conflict, consequently changing the information environments of disputes, a critical component of the resolution process.

A balanced approach also assists in contextualising and defining the conflict by identifying underlying interests, worries and concerns; thus providing the foundation upon which reconciliation can begin. This is made possible due to the reformation of communication distribution made possible through the internet. Instead of being a top-down process in which traditional media outlets and government authorities disseminate information to the public, many-to-many interactivity becomes achievable.

This is made a reality through the open access, and multi-directional character of the internet, allowing for the rapid exchange of information, often from few or individual sources, regardless of geographical or national boundaries; thus serving to circumvent State censorship or information manipulation attempts. 'Information sovereignty' (Regan, 2000, p. 8) becomes inadvertently challenged by the internet, making it impossible for authorities in totalitarian countries for instance, to prevent their citizens from accessing alternative online news sources (Matic, 1999, p. 3). Cyprus provides such an example, in which the inhabitants from the two sides of the island had been denied the opportunity to communicate via traditional means of face-to-face communication, telephone or traditional media until April 2004. Local authorities and administrators however, were unable to maintain the disruption in communication because of the public's use of internet (Gumpert, 1997, p. 287). Hence, the internet can be used as a medium of communication between conflicting parities to reconstruct relations by fostering understanding tolerance, and reciprocal respect through educative information (Breuilly, 1994, p. 406).

Although a communication line is not the definitive solution for decreasing tensions or stopping conflicts, it contributes significantly towards planting the seeds for change and finding a peaceful solution, as open lines of communication are a prerequisite for conflict resolution (Bachman, 1996, p. 2-5). In peace media 
literature, scholars have suggested that peace media can contribute to a declining evolution of the conflict dynamic curve of violence. Peace media can therefore be an important factor in the process of conflict prevention, conflict resolution, reconciliation and confidence building. Robert Karl Manoff (1997), enumerates the potential role of the media in prevention and conflict management as follows:

- Channeling communication between parties

- Educating the parties

- Engaging in confidence-building measures

- Counteracting misperception and incendiary rumours

- Analysing the conflict

- De-objectifying and de-humanising conflict parties to each other

- Identifying the interests underlying the issues

- Providing an emotional outlet

- Encouraging a balance of power among unequal parties

- Framing and defining the conflict

- Engaging in face-saving and consensus-building measures

- Engaging in the solution-building process

Following on from the definition of peace media, it becomes possible to define online peace activism initiatives (or e-peace) as the following: All kinds of initiatives with a mission to use facets of the internet, such as electronic mail, the World Wide Web and social media to achieve peaceful conditions of life and resolution of conflict, or counteract hate media, by proposing balanced information, and offering alternative and open sources of information (Marks \& Janssen, 2000, p. 3-4) through 'Awareness/Advocacy, Organisation/ Mobilisation, Action/Reaction' (Vegh, 2003). As such, online peace initiatives are located within the theoretical framework of peace media and within the literature on the use of media for conflict prevention and conflict management (Hanitzsch, 2004).

\section{Online war and peace activism}

In practice however, the internet is a medium that can be simultaneously utilised for peaceful or violent initiatives. Online communication in particular, for example, can be used to break down or reinforce existing barriers because the internet brings together previously disparate and disconnected cultures, religions and societies into closer proximity with each other (Wheeler, 2000, p. 208). Thus, if approached 'incorrectly', frequent communications between parties can be used to strengthen, even highlight differences between ethnic, racial and social groups, ultimately increasing tensions with and laying the foundations for hate and violence.

The first so-called 'web war' or 'internet war', however, is the war in Kosovo (Hall, 2000, pp. 387-404). The novel term 'web war' refers primarily to the introduction of a new medium along which a conflict is waged or understood; 
previous examples of which include the first 'television war' of Vietnam, and the first 'satellite war' of the first Gulf War of 1991. Hall (2000) argues that Kosovo is the first 'web war', because the volume and range of information about this war on the internet had radical implications for how global audiences perceived the war and how the different parties during the conflict dispersed war propaganda and information.

Conversely, Jon Katz (1999), contests this point of view, arguing that although coverage of the Kosovo war on the internet was enormous, the ultimate impact had no significance. According to Katz none of the reports found on the internet adequately shaped or influenced the policy of either side, nor did these affect the manner in which the fighting was conducted.

Setting aside the arguments regarding the significant or insignificant influences the online information war had on strategies or tactics during the Kosovo war, the internet itself had become a new battleground for online activists. This new movement manifested itself during the Kosovo war, with web hacks being a common practice. Examples include a US hacking group, breaking into government sites and posting statements such as, 'Tell your governments to stop the war', or replacement and defacement campaigns of at least five websites displayed the black and red banner 'Free Kosovo' by the Kosovo Hackers group (Denning, 2001, p. 72). Denning (2001, p. 70) illustrates this growing trend as hacktivism, a fusion of hacking with activism, which will be discussed in more detail later:

The practice of online activism has spread, manifesting itself into different conflicts. In the fall of 2000, the clash of Palestinian and Israeli forces, led Arab and Israeli hackers to participate in the conflict through online initiatives. According to the Middle East Intelligence Bulletin, the encounters began in October, shortly after the Lebanese Shiite Hezbollah movement abducted three Israeli soldiers. Pro-Israeli hackers responded by crippling the guerrilla movement's website, which had been displaying videos of Palestinians being killed in recent clashes and which had called on Palestinians to kill as many Israelis as possible. Pro-Palestinian hackers retaliated, shutting down the main Israeli government website and the Israeli Foreign Ministry website. An Israeli hacker planted the Star of David and some Hebrew text on one of Hezbollah's mirror sites, while pro-Palestinian hackers attacked additional Israeli sites, including those of the Bank of Israel and the Tel Aviv Stock Exchange. Hackers from around the world also began to participate, assisting in sabotaging over 100 websites, helping to disrupt the internet service within the Middle East.

Ethnopolitical conflicts between the Sri Lankan army and the Tamil Tigers, East Timor guerrillas and the Indonesian army, China and Taiwan, China and US, China and Japan, Hungary and Romania, and India and Pakistan are just some of the documented encounters with equivalent online cyber activism and 
wars (Vegh, 2003, p. 80). It is thus being argued that the prediction made in 2001 by Denning that in the future 'every major conflict in the physical world will have a parallel operation in cyberspace. Further, there may be cyberspace battles with no corresponding physical operations' (Denning, 2001, p. 74) is already true.

In contrast to the above, in 1997 the Nobel Peace Price was given to the online peace initiative for the ban of landmines in conflicts. Jody Williams, from the small town of Putney, Vermont, used her e-mail account to co-ordinate with more than 700 organisations in more than 60 countries that made up the coalition against the use of landmines (Studemeister, 1998, p. 2). This landmark accomplishment thus ushered in a new age demonstrating the potency of the internet coupled with a strong initiative, particularly a peaceful one.

Online activism has in this sense been able to aid ethnic minorities and grassroots activists in their struggle. The creation of a cyberspace community by the Zapatistas is an example in which the internet was used to resist a regime. In their struggle for democratic rights, land and jobs the Indians of Chiapas used the internet to sway international public opinion and to put international pressure on the Mexican government (Lie, 2001, p. 23-22; Cleaver, 1998). The decentralised structure of the internet helped to circumvent all censoring regulations and to put pressure on the Mexican government. Given the way the traditional media works, however, this success would not have been possible without the internet (Zurawski, 1996, p.6).

Burma is another example in which the internet was able to make a difference regarding the ethnopolitical conflict through the management of information. Burmese and non-Burmese activists from the United States and elsewhere used the internet to create grassroots support for the pro-democracy movement in Burma. Furthermore the internet was used to influence international public opinion and attract the interest of more traditional news media. According to Danitz and Strobel (1999, p. 2), the internet was crucially influential in forcing the passage of a series of laws regarding business and political dealings with Burma.

More recently, social media was introduced into the equation of online activism. Social media has been defined as 'all the devices and platforms that allow users globally to virtually create and share information with each other. Platforms are the virtual spaces that allow users to come together, and create and share information. Devices are the computing technologies that enable users to access the platform' (Gupta \& Brooks, 2013, p. 18). Unlike traditional media, social media are 'by nature' a two-way or many-to-many communication. This approach of working from the bottom-up has in the past few years enabled online activists to raise momentum for events like the Tunisian Jasmine Revolution, the happenings at Cairo's Tahrir Square, and the ongoing civil war in Syria.

In early 2011, the public suicide of Mouhamed Bouazizi quickly spread 
throughout Tunisia via social network platforms like Facebook and Twitter, igniting protests that ultimately led to the overthrow of the Tunisian government (Gupta \& Brooks, 2013, p. 4). Yet, news organisations such as A1 Jazeera and the British Broadcasting Corporation (BBC) did not pick up on the story until they started noticing the thousands of tweets and multiple YouTube videos coming out of Tunisia (Gupta \& Brooks, 2013, p. 5).

Inspired by the achievements of the Tunisian protesters, Egypt was struck by the revolution as well. By using Twitter, Egyptian protesters communicated logistical information such as the time and place of organised protests, as well as information on the whereabouts of government forces and methods to protect oneself from police attention. Even more impressive was the way in which the protesters had set-up specific hashtags that only likeminded people were knowledgeable about in order to stay under the government radar (Gupta \& Brooks, 2013, p. 7).

The social media techniques and revolutionary fervor used during these aforementioned revolutions did not limit themselves to the Arab world. Moreover, the Behsir 2.0 Rally in Malaysia as well as the Occupy movement both drew upon the same principles and platforms used in the Arab revolutions. In a nutshell, it is important to bear in mind that the online activists of today are ever more connected, outspoken, culturally aware, and as Philip Seib points out: 'People born in the last decades of the twentieth century constitute the first truly global generation. New information and communication technologies connect them to each other regardless of physical distance or political obstruction' (Seib, 2012, p. 16).

In addition, the new generation of online activists do not spend time on endless remarks outlining their beliefs, rather, they use an 'instant ethos' that enables them to reach many likeminded individuals in a short statement that is quickly spread (Gurak \& Logie, 2003, p.31). In some cases, short statements are not even made because real-time footage can be shared in a matter of seconds due to the technological advancements of mobile phones and phone networks. In the Syria conflict for example, a large amount of the footage shown through the Western media often comes from young men and woman who uploaded it on social media networks, such as YouTube, Twitter, Facebook and Instagram.

\section{Advantages and constraints of online activism in ethnopolitical conflicts}

As is evident from the above examples, one of the main advantages of an e-initiative is its use of the internet as an organisational tool, for both on line and offline actions. A handful of organisers can rapidly generate dozens of letters and e-mails to decision-makers, the cyber equivalent of lobbying, with a few well-timed on-line appeals. Unlike other media forms, the internet enables an increase in speed, is inexpensive, integrates and converges different media forms such as text, audio, visuals and moving pictures, and allows for anonymity that 
makes it easier to express opinions without risking social sanctions.

Anonymity, in conjunction with the internet's mass connectivity, also allows members of the international community to comment and affect domestic, local and international public opinion, which in itself is potentially problematic. This is because, while the internet can help foster understanding and sensitivity it also works to solidify prejudices and reinforce existing (often incorrect) convictions, thus using the online space to rant instead of productively exchanging views (Ward, 2005, p. 138). This, however, is the challenge of operating within a pluralistic world.

In return, the proliferation of new ICTs and internet access has gradually been altering the traditional structure of old media despite their continuous dominance in the new on-line news world. This is because the public is able to access multiple and alternative sources of information, unlike off-line traditional media sources that presented limited viewpoints. The civic journalists and online activists become more able to deliver 'purer' forms of information often due to citizen initiatives or public journalism. Civic journalism above all, seeks to counter citizen alienation from the political process (Ward, 2005, p. 139).

When framing e-initiatives for the information management of ethnopolitical conflicts, it is also useful to put these initiatives in the wider context of the literature on information technology (IT) and society, and the relative media effects theory that reveal a number of contradictions of the 'claims' made by both politicians and activists alike.

First, when analysing the impact of the internet we have to consider the dispersion of internet users in societies. It is impossible to assess the exact number of users in the world, however, the majority of the computers linked to the internet are found in the United States, Europe and Asia (Computer Industry Almanac). For example, e-initiatives in Cyprus, Greece or Turkey, which are wired countries will have far larger potential than initiatives in the African continents (Deflander \& Attias, 2002, p. 4), but far smaller than the ones in USA or North Europe.

Second, E-advocacy initiatives severely suffer from existing language barriers. Especially among e-peace groups who try to get in touch with one another, English (to a limited extent, French) is the language used. This in particular excludes large parts of populations that do not speak English and thus leaves these initiatives once again in the hands of an educated elite or the diaspora. Important to note here is that there is a clear distinction between those experiencing wrongdoing and wanting to get out of their situation, and those campaigning to help those suffering through e-initiatives. This problem of being somewhat disconnected, can bring about misunderstandings as to what the priorities are for those on the ground. At the same time, this indicates the importance of groundwork, assessment of the situation, analysing the needs and beliefs of people on the front; something that does not necessarily come with e-initiatives. 
Third, the impact of online activism on the information management of ethno-political conflicts is crucial for the flow of communications during crises (Reljic, 1998, p. 39) making the question of timing of e-initiatives very important. Research has proven that the need for information and communication is significantly higher in times of political, economical, cultural, religious or social crises (Kellow \& Steeves, 1998, p. 110). Providing communications remains key in times of crisis, especially with regards to the morale of people, taking away fear and uncertainty, and providing protection by announcing the so-called 'safe spots'. For example, BBC News Online experienced a five-fold increase in traffic from the Balkans during the conflict in that region, while CNN.com experienced some of the heaviest traffic to that date, as its website usage specifically on the Balkans, increased tenfold during the bombing of Serbia in the Kosovo war in 1999 (Hall, 2000, p. 389).

Surprisingly, negative information and propaganda can equally satisfy the information-need of those suffering in a crisis. During the civil war in former Yugoslavia, research demonstrated that the Croatian population considered propaganda as necessary and normal, even though they knew that it was biased and propagandistic information. Such seeming contradiction can be explained by the great information-need of people who are living in times of uncertainty (Reljic, 1998, p. 52).

Finally, the effects of online activism have also been misrepresented by both activists and politicians as the effects of previous political communication through traditional media have. The attribution of the Arab 'Spring' to Facebook revolutions have caused an embarrassment to Facebook itself, which was quick to distance itself from taking the credit (and the responsibility). At the same time, documentaries on British television were quick to talk and indirectly give credit to training on the use of social media for activism that some of the organisers of the demonstrations received abroad. The fifteen-year experience in online activism of organisations such as Search for Common Ground and the evaluations of these organisations reveal that even when there is considerable impact at the informational level, and sufficient impact on the attitudinal level, there is very little or no impact at the behavioural level when online activism takes place in isolation from other peace initiatives at political or economical level (Search for Common Ground, Independent Programme Evaluations, Middle East and FYR Macedonia).

\section{Current trends of online activism}

While social media will continue to play a significant role in online activism, the role of whistleblowers have taken up a central role in fueling protests and providing information to the people. Wikileaks, the most known and perhaps notorious website for disseminating information acquired via anonymous 
sources, shook global politics when it revealed detailed information on the Iraq war and US diplomatic practices (Leigh \& Harding, 2011, Sifry, 2011; Greenberg, 2011).

This quest for classified information is particularly interesting because of the scale of information which Wikileaks and persons such as Edward Snowden managed to acquire. Subsequently, the usage of traditional media (i.e. newspapers such as Der Spiegel, The Guardian and others) in combination with their own website, enabled Julian Assange, the founder of Wikileaks, to target a wide audience (Sifry, 2011), encompassing all ages. This in itself was particularly important due to the gravity of the released information.

Whereas activists in the past had to base themselves on general assumptions, news outlets and occasionally inside information, Wikileaks has provided them with clear cut information that in itself fuels protest (e.g. the 'Collateral Murder video). In releasing such large quantities of sensitive information, Wikileaks put itself against the wall. In the weeks following their 'Diplomatic Cables' publication (Sifry, 2011), attempts were made to take the whistleblower website offline and freeze their assets.

In response to the governmental actions taken against Wikileaks, a newly developed form of activism based on hacktivism emerged. In the past, a hacktivist was essentially one person who was a fantastic computer programmer but could be perceived as a cyber criminal because (s)he would detect weak spots in networks, computer systems and others, and subsequently target them. This could be done for reasons of entertainment, on assignment, for purely criminal outcomes or as a response to certain happenings (e.g. political campaigns) (Olson, 2012, p. 6-7). Today, a hacktivist is perceived as a hacker with political motives.

The Wikileaks saga brought about a new collective that named itself Anonymous. This congregation of hacktivists operates with no clear hierarchy or conventional structure as one would find in most activist groups. What is clear, however, is that this collective includes thousands of members that do not know each other, have never seen each other and essentially do not talk to each other. Moreover, they operate in an ad hoc fashion depending on what one of the members or 'leaders' proposes and whether a sufficient number of skilled fellow hackers can be 'recruited' (Olson, 2013, p.8).

The main method of working for Anonymous was a technique in which thousands of users overload a website's server with traffic in order for it to fall offline. This technique was most notably used in response to the Wikileaks saga, targeted specifically against Visa, Mastercard and Paypal (Olsen, 2013, p. 6, p. 11) in order to make a definitive statement with regards to freezing Wikileaks' assets (Olson, 2013, p.107-124).

Similarly, Wikileaks requested those who supported them to download an encrypted file called 'the insurance', which automatically safeguards the information 
Wikileaks acquired. The idea behind this is that if anything were to happen to Assange or the website, the unbreakable key to open the document will be released. In addition, WikiLeaks requested supporters to 'mirror' its website in order to keep it online. Such activism had never been seen before. Moreover, the level of civil disobedience involved by simply downloading a file that includes an unbreakable code, can cause serious damage to governments if released.

These new trends and possibilities foster opportunities for the activist of today. The fast and efficient organisation of Anonymous as well as the rather effective methods of Wikileaks' quest for transparency, can bring online activism to a whole new level, as we currently see with the revelations of the Panama Papers.

\section{Conclusion: The end of hypocrisy}

It is evident that these new trends in online activism pose new opportunities and a number of advantages. First and foremost, the speed with which the general audience is fed with information is remarkable. Whereas CNN made a giant leap in journalism approaches when Peter Arnett reported live from Baghdad during the 1990-91 Gulf War (Herman \& Peterson, 2000, p.111), we can now receive information from any front at any time of the day and from any angle we desire. Second, social media presents great opportunities for protest movements that can easily recruit likeminded followers worldwide and rapidly organise in order to get a global message out.

Third, more than ever, people are exercising their right to free speech and freedom of expression. Whether it is by 'liking' something, uploading a video, copying statements or commenting on posts, the important factor here is that the new generations are again directly involved in things that matter to them.

Lastly, the ease in which information is available nowadays contributes to the growing hunger (Seib, 2012, p. 16) of social media societies that can ultimately lead to a better understanding of conflicts, and henceforth contribute to peace. Social media activism allows the audience to shape better worldviews because there is currently monitoring on virtually every ongoing conflict whereas in the past the traditional offline media were 'highly selective in their focus on wars and conflicts,' (Boyd-Barret, 2004, p. 26). For example, compared to the 2001 Afghanistan and 2003 Iraq war, many more (four million) lives were lost in the period between 1997-2003 in the Democratic Republic of Congo (DRC), yet, there was little publicity on the matter (Allan \& Zelizer, 2004, p. 26).

On the other hand, it is important to note that despite the momentous revolution in online activism, a number of new problems have arisen. First, the decentralisation of media as a consequence of social networks and other new technologies do not necessarily pose a de facto improvement in journalism. It is evident that different news agencies and journalists have their own sources and biases, yet, it becomes much harder to track these when there is a sudden 
oversaturation in available information whose sources are hard to verify. In addition, every newsfeed, tweet or YouTube upload is created by someone with an agenda, whether it is genuine or not, which is never very clear (e.g. direct footage coming in from the Syrian front).

Second, social media can potentially fragment the multiple organisations concerned with various fields of online activism. That is not to say that there is less interest in activism. On the contrary, it is clear that the number of online initiatives has incrementally increased. Yet, for initiatives to be effective and efficient, classic models of big organisations coordinating with their supporters, are still the better way to go. It seems to be easy these days to quickly start new initiatives that do not necessarily differ in objective but are more likely set-up in the aftermath of personal battles.

Third, Gupta and Brooks point out that: 'Social media can help create and exacerbate security problems in even the most secure and stable parts of the world and become even more complicated for security forces to deal with when they involve location-specific technologies' (Gupta \& Brooks, 2013, p. 9). In other words, while social media holds great potential, it brings with it severe security problems at the personal, regional, national and international level.

Furthermore, building on this latter statement, it is important to outline how social media can be used just as much to spread hate and recruit young people who are easy to influence. A good example of this can be found in the context of the Syrian conflict. Extremist groups such as Sharia4Belgium have been heavily recruiting young men through crowdsourcing.

The road ahead is still unclear, yet it seems that as the Deputy Assistant Secretary-General of NATO (and the organisation's spin doctor during the Kosovo war), Jamie Shea summarised in a recent speech, what we will get in the ethno-political conflicts communication environment is more fragmented communication, more floating supporters and opponents, more cyber warfare and cyber activism, more two-way and multi-polar communication, more embedded journalism, more media centres in security organisations, even more ubiquitous social media and as a result the end of hypocrisy of political leaders and activists alike, since very few things will remain private (Shea, 2013). And as Zizek (2011, p. 408 and p. 410) argues:

from the very outset, there was something about the WikiLeaks activity which went well beyond the liberal topic of the free flow of information. We should not look for this excess at the level of content. The only truly surprising thing about the revelations is that there was no surprise in them: didn't we learn exactly what we expected to learn? All that was disturbed was the capacity to 'keep appearances': we can no longer pretend that we don't know what everyone knows we know. this is the paradox of the public space: even if everyone knows an unpleasant fact, stating it 
publicly changes everything. (...) And this, exactly, is our situation today: we are facing the shameless cynicism of the existing global order whose agents only imagine that they believe in their ideas of democracy, human rights, etc., and through moves like the WikiLeaks disclosures, the shame (our shame for tolerating such power over us) is made more shameful by publicising it.

\section{References}

Allan, S., \& Zelizer, B. (Eds) (2004). Reporting war: journalism in wartime. London, UK: Routledge.

Anwar A. E. (s.d.). The use of the internet to serve peace and bring people together. Retrieved from www.unesco.org/webworld/infoethics-2/eng/papers/paper_4.htm

Arqilla, J. \& D. Roneldt (1998), Cyberwar is coming! In Inforwar, (Eds.). G. Stocker and C. Schopf, (Eds.), Infowar. (pp. 24-500, Wien: Springer.

Bachman E. (1996). Digital communication via the internet in a war zone: conflict resolution and the internet. Retrieved from www.isoc.org/isoc/whatis/conferences/ inet $/ 96 /$ proceedings $/ \mathrm{h} 2 / \mathrm{h} 2 \mathrm{~h} 2 . \mathrm{htm}$

Boyd-Barrett, O. (2004). Understanding the second casualty. In Allan, S. and Zelizer, B. (Eds). (2004). Reporting war: journalism in wartime (pp. 25-43). London, UK: Routledge.

Breed, W. (1980). Dissertations on sociology: the newspaperman, news and society. New York: Arno Press.

Breuilly J. (1994). Nationalism and the state. Chicago-Manchester: University of Chicago Press.

Caparini, M. (2005). Media and the security sector: Oversight and accountability. In Caparini, M. (Ed.), Media in security and governance: the role of the news media in security oversight and accountability. (pp. 15-51). Baden-Baden, Germany: Nomos Verlagsgesellschaft.

Cleaver H. (1998). The Zapatistas and the electronic fabric of struggle. Retrieved from www.eco.utexas.edu/faculty/Cleaver/zaps.html

Cottle, S. (2006). Mediatized conflict. New York: Open University Press.

Council of Europe (2007). Cyberterrorism: the use of the internet for terrorist purposes. Strasbourg: France.

Danitz T. \& W. Strobel (1999). Networking dissident. Cyber-Activists use the internet to promote democracy in Burma. USIP Virtual Diplomacy Report. Retrieved from www.usip.org/vdi/vdr/vburma

Deflander J. \& L. Attias (2001). L'utilisation d'internet au sein des radios communautaires : les autoroutes de l'information ne sont pas encore gourdonnees. Institut Panos. Afrique de l'Ouest. Département Radio.

Denning D. (2001). Cyberwarriors. Activists and terrorists to cyberspace. Harvard International Review, Summer 2001, pp.70-75

Gans, H. (1979). Deciding what's news. New York: Random House.

Giles, B. (2000). Journalism in the era of the web. Nieman Reports, Winter 2000, p. 3.

Giri, S. (2010). WikiLeaks beyond WikiLeaks? available online at www.metamute.org Gray, C. H. (2005). Peace, war and computers. New York: Routledge

Gumpert, G. \& S. Drucker (1997). The question of identity in a divided landscape: the case of Cyprus, Res Publica, 39(2). 
Gupta, R., \& Brooks, H. (2013). Using social media for global security. Indianapolis, IND: John Whiley \& Sons.

Gurak, L. \& Logie, J. (2003). Internet protests, from text to web. In McCaughey, M. \& Ayers, M. D. (Eds.), Cyberactivism: online activism in theory and practice (pp. 25-45). New York: Routledge.

Galusky, W. (2003). Identifying with information: citizen empowerment, the internet and the environmental toxins movement. In MccCaughey, M. \& Ayers, M. D. (Eds.), Cyberactivism: online activism in theory and practice (pp. 185-209). New York: Routledge.

Hall, J. (2000). The First Web War: 'Bad things happen in unimportant places'.Journalism Studies, 1(3), 387-404.

Hamelink, C. (1999). ICTs and social development. The global policy context. (UNRISD discussion paper) Geneva: UNRISD.

Hanitzsch, T. (2004). Journalists as peacekeeping force? Peace journalism and mass communication theory, Journalism Studies, 5(4), 483-495.

Herman, E. S., \& Hammond, P. (Eds) (2000). Degraded capability: the media and the Kosovo crisis. London, UK: Pluto Press.

Howard, R. (2005). The media's role in war and peace-building. In Caparini, M. (Ed.), Media in security and governance: the role of the news media in security oversight and accountability. (pp. 147-161). Baden-Baden, Germany: Nomos Verlagsgesellschaft.

ICG (2006). In their own words: Reading the Iraqi insurgency, in ICG Middle East Report No 50, 15 February 2006

Jordan, T. \& Taylor P. A (2004). Hacktivism and cyberwars: rebels with a cause? London: Routledge.

Lynch, J., \& McGoldrick, A. (2005). Peace journalism. Gloucestershire: Hawthorn Press.

Lynch, J. (2005). Reporting the world: an ethical challenge to international news. In Caparini, M. (Ed.), Media in security and governance: the role of the news media in security oversight and accountability. (pp.97-119). Baden-Baden, Germany: Nomos Verlagsgesellschaft.

Katz, J. (1999). War coverage is not the net's strength. Retrieved from www.freedomforum.org/templates/document.asp?documentID=11507

Kellow, C., \& Steeves, L. (1998). The role of radio in the Rwandan genocide. Journal of Communication, summer 1998, pp.107-128.

Lie, R. (2001). Community development and the internet. Paper prepared for presentation at the International Conference on Information Technology, Communications and Development, 29-30 November 2001, Kathmandu, Nepal.

Manoff, R. K. (1997). The media's role in preventing and moderating conflict. Paper prepared for the Virtual Diplomacy conference by the USIP in Washington, D.C. 1-2 April 1997, Retrieved from www.org/oc/vd/confpapers/manoff.htm

Marks, J., \& Janssen, D. (2000). Counteracting hate media. Retrieved from www.rnw.nl/ realradio/dossiers/html

Matic, V. (1999). Authoritarian society and information guerrilla: discovering the values of civil society with the help of the net (the case of B92). International Studies Association Conference, 17-19 February, Washington, D.C. retrieved from www.nyu/ globalbeat/index.html

McCaughey, M., \& Ayers, M. D. (Eds.) (2003). Cyberactivism: online activism in theory and practice. New York: Routledge.

Massing, M. (1984). The network newscasts: Still hot off the presses, Channels 47: 47-52.

Mesthene, E.G. (1986). Technology: the opiate of the intellectuals. In Technology and the future. New York, St. Martins. 
Olsen, Parmy (2012). We are Anonymous: inside the hacker world of Lulzsec, Anonymous and the global cyber insurgency. London, UK: William Heineman.

Regan, T. (2000). Technology is changing journalism. Nieman Reports, Winter 2000, pp. 6-9.

Reljic, D. (1998). Killing screens: medien in zeiten von konflikten. Dusseldorf, Germany: Dorste.

Search for Common Ground (1999). Independent Evaluations, Middle East and FYR Macedonia Programmes.

Seib, P. (2008). The Al Jazeera effect: how the new global media are reshaping world politics. Washington, DC: Potomac Books.

Seib, P. (2012). Real-time diplomacy: politics and power in the social media era. New York: Palgrave Macmillan.

Shea, J. (2013). GRACM_Module 4: A New Information Environment: Media, Conflict and Crisis Communication, Brussels, Belgium.

Studemeister, M. (1998). The impact of information and communications technologies on international conflict management. ASIS-Bulletin, February-March 1998.

Sonwalkar, S. (2004). Out of sight, out of mind? The non-reporting of small wars and insurgencies. In Allan, S., and Zelizer, B. (Eds), Reporting war: journalism in wartime ( pp. 206-273). London, UK: Routledge.

Tumber, H. \& Prentoulis, M. (2003). Journalists under fire: subcultures, objectivity and emotional literacy. In Thussu, K. D., and Freedman, D. (Eds.) (2003). War and the media reporting conflict 24/7 (pp. 215-231). London: Sage Publishing.

Vegh, S. (2003). Classifying forms of online activism: the case of cyberprotests against the World Bank. In McCaughey, M. \& Ayers, M. D. (Eds.), Cyberactivism: online activism in theory and practice. New York: Routledge.

Vidal J. (2000, February 3-9). The world@war. Guardian Weekly.

Ward, Stephen (2005). Global Journalism ethics: ethics in a time. In Caparini, M. (Ed.), Media in security and governance: the role of the news media in security oversight and accountability. (pp. 131-147). Baden-Baden, Germany: Nomos Verlagsgesellschaft.

Weimann G. (2004), www.terror.net, How modern terrorism uses the internet. United States Institute for Peace, March 2004, Special Report 116. Retrieved from www. usip.org/pubs/specialreports/sr116.pdf

Wheeler, M. (2000). Politics and the mass media. Oxford, UK: Blackwell.

White, A. (2005). Security and the media. In Caparini, M. (Ed.), Media in security and governance: the role of the news media in security oversight and accountability (pp. 51-65). Baden-Baden, Germany: Nomos Verlagsgesellschaft.

Zurawski, N. (1996). Ethnicity and the internet in global society. Retrieved from www. isoc.org/isoc/whatis/conference/inet/96/proceedings/e8/e8_1htm

Acknowledgement: The article is inspired by the research done by the author for the 7 th European Framework Programme project INFOCORE (In)forming conflict, prevention, response and resolution: The role of media in violent conflict) that is funded by the European Union.

Dr Georgios Terzis is an associate professor at Vesalius College and senior associate researcher at the Institute for European Studies, Vrije Universiteit, Brussels, Belgium. He is the founding chair of the Journalism Studies Section of the European Communication Research and Education Association georgios.terzis@vub.ac.be 